Journal of Animal and Veterinary Advances 11 (1): 26-29, 2012

ISSN: $1680-5593$

(C) Medwell Journals, 2012

\title{
The Echinoderm Fauna of Gokceada Island (NE Aegean Sea)
}

\author{
Herdem Aslan-Cihangir \\ Gokceada School of Applied Sciences, Canakkale Onsekiz Mart University, \\ P.O. Box 8, 17760 Gokceada, Canakkale, Turkey
}

\begin{abstract}
The Echinoderm fauna of Gokceada island (NE Aegean sea) was studied in 2011 from 22 stations at depths ranging from $0.5-45 \mathrm{~m}$ by means of bottom trawling and snorkeling. Additionally, temperature, salinity, dissolved oxygen, $\mathrm{pH}$, TDS and conductivity of water were measured on board. A total of 626 specimens belonging to 25 species ( 7 Asteroidea and Echinoidea, 6 Ophiroidea, 4 Holothoridea and 1 Crinoidea) were identified. The dominant species was the echinoid Psammechinus microtuberculatus (Blainville, 1825). According to the result of cluster analysis based on the precence/absence of Echinoderm species, Gokceada island had a species composition similar to that of Bozcaada island while both islands were different from the Canakkale strait. However, ANOSIM they were not found to be statistically different $(p=0.3)$.
\end{abstract}

Key words: Echinodermata, Gokceada island, Aegean sea, benthos, diversity, Turkey

\section{INTRODUCTION}

The Aegean sea is the Northeastern extension of the Mediterranean sea. Gokceada island, the biggest island of Turkey $\left(289 \mathrm{~km}^{2}\right)$ which is located in the Northern Aegean sea at the mouth of the Canakkale strait is situated nearly $25 \mathrm{~km}$ off the coast of the mainland.

Although, the Echinoderm fauna of the Turkish Aegean sea coasts consist of 69 species (Ozaydin et al., 1995; Zaitsev and Ozturk, 2001; Cinar et al., 2002) according to the existing literature only Antedon mediterranea (Lamarck, 1816), Amphiura chiajei Forbes, 1843, Ophiura ophiura (Linnaeus, 1758), Cidaris cidaris (Linnaeus, 1758), Sphaerechinus granularis (Lamarck, 1816), Spatangus purpureus (Muller, 1776), Stichopus regalis (Cuvier, 1817), Brisingella coronata (Sars, 1871), Brissopsis lyrifera (Forbes, 1841) have been reported from Gokceada island (Ozaydin et al., 1995). It is obvious that the number of Echinoderm species must be higher than 9 species, taking into account that 23 species have been reported from Bozcaada island, located in adjacent water and smaller than Gokceada island and 25 species from the Canakkale strait (Aslan-Cihangir and Pancucci-Papadopoulou, 2011).

The purpose of this study was to determine the Echinoderm species living in the coast of Gokceada and to investigate some of their ecological properties.

\section{MATERIALS AND METHODS}

Material examined in this study were collected between 25th March and 8th April, 2011 from depths ranging between 0.5 and $45 \mathrm{~m}$ by means of beam-trawl

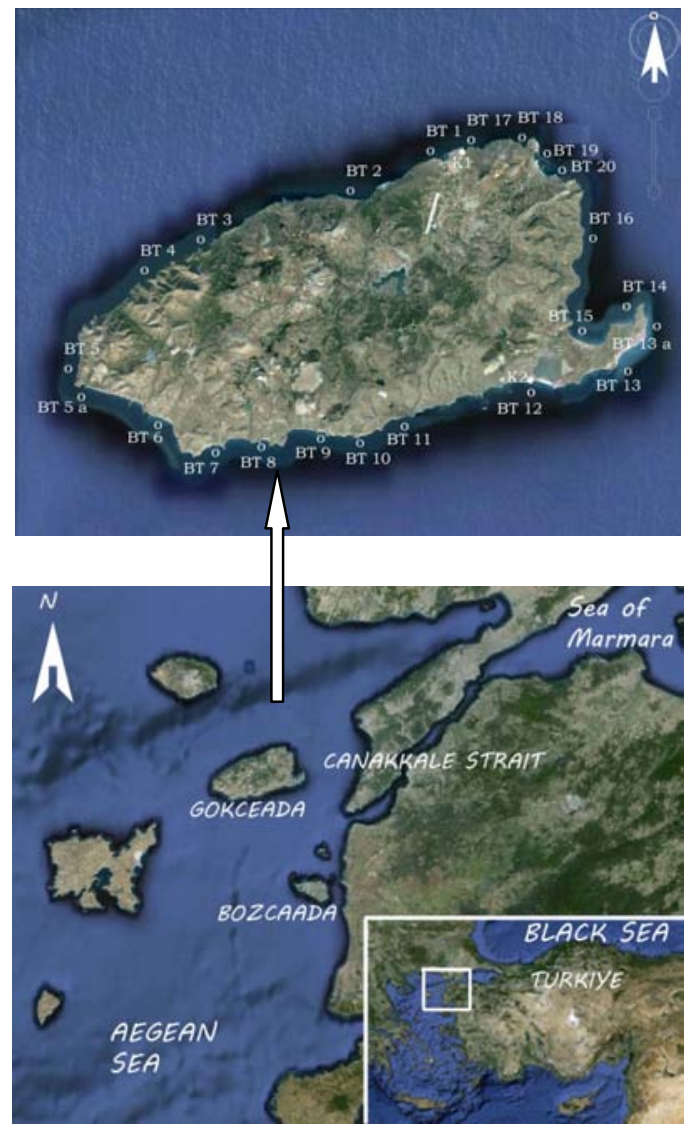

Fig. 1: Location of sampling Stations in Gokceada island

(Fig. 1) and by snorkeling. All benthic samples were sieved through a $0.5 \mathrm{~mm}$ mesh size sieve and fixed in $4 \%$ formaldehyde-sea water solution. In the laboratory, the 
Table 1: General properties of the study area

\begin{tabular}{|c|c|c|c|c|c|}
\hline No.of station & Latitude & Longitude & Date & Depth (m) & Sediment types \\
\hline BT1 & $40^{\circ} 13^{\prime} 55^{\prime \prime}$ & $25^{\circ} 52^{\prime} 54^{\prime \prime}$ & 25.03 .2011 & $20-45$ & Posidonia \\
\hline BT2 & $40^{\circ} 12^{\prime} 45^{\prime \prime}$ & $25^{\circ} 50^{\prime} 11^{\prime \prime}$ & 25.03 .2011 & $25-35$ & Posidonia \\
\hline BT3 & $40^{\circ} 11^{\prime} 39^{\prime \prime}$ & $25^{\circ} 45^{\prime} 07^{\prime \prime}$ & 25.03 .2011 & $20-40$ & Posidonia \\
\hline BT4 & $40^{\circ} 10^{\prime} 40^{\prime \prime}$ & $25^{\circ} 42^{\prime} 41^{\prime \prime}$ & 25.03 .2011 & $20-40$ & Posidonia \\
\hline BT5 & $40^{\circ} 08^{\prime} 06^{\prime \prime}$ & $25^{\circ} 39^{\prime} 50^{\prime \prime}$ & 04.04 .2011 & $25-30$ & Posidonia dead matte \\
\hline BT5a & $40^{\circ} 07^{\prime} 20^{\prime \prime}$ & $25^{\circ} 40^{\prime} 11^{\prime \prime}$ & 04.04 .2011 & $20-30$ & Posidonia dead matte \\
\hline BT6 & $40^{\circ} 06^{\prime} 25^{\prime \prime}$ & $25^{\circ} 43^{\prime} 08^{\prime \prime}$ & 04.04 .2011 & $23-40$ & Posidonia dead matte \\
\hline BT7 & $40^{\circ} 05^{\prime} 46^{\prime \prime}$ & $25^{\circ} 45^{\prime} 06^{\prime \prime}$ & 04.04 .2011 & $12-25$ & Posidonia \\
\hline BT8 & $40^{\circ} 05^{\prime} 56^{\prime \prime}$ & $25^{\circ} 46^{\prime} 49^{\prime \prime}$ & 04.04 .2011 & $20-40$ & Posidonia \\
\hline BT9 & $40^{\circ} 06^{\prime} 09^{\prime \prime}$ & $25^{\circ} 48^{\prime} 56^{\prime \prime}$ & 04.04 .2011 & $20-35$ & Posidonia dead matte \\
\hline BT10 & $40^{\circ} 06^{\prime} 01^{\prime \prime}$ & $25^{\circ} 49^{\prime} 26^{\prime \prime}$ & 05.04 .2011 & $20-40$ & Codium bursa \\
\hline BT11 & $40^{\circ} 06^{\prime} 38^{\prime \prime}$ & $25^{\circ} 52^{\prime} 37^{\prime \prime}$ & 05.04 .2011 & $20-40$ & Codium bursa \\
\hline BT12 & $40^{\circ} 07^{\prime} 31^{\prime \prime}$ & $25^{\circ} 56^{\prime} 34^{\prime \prime}$ & 05.04 .2011 & $20-35$ & Posidonia dead matte \\
\hline BT13 & $40^{\circ} 08^{\prime} 34^{\prime \prime}$ & $26^{\circ} 00^{\prime} 59^{\prime \prime}$ & 05.04 .2011 & $10-20$ & Sandy \\
\hline BT13a & $40^{\circ} 09^{\prime} 06^{\prime \prime}$ & $26^{\circ} 01^{\prime} 05^{\prime \prime}$ & 05.04 .2011 & $10-20$ & Sandy \\
\hline BT14 & $40^{\circ} 09^{\prime 3} 2^{\prime \prime}$ & $26^{\circ} 00^{\prime} 07^{\prime \prime}$ & 05.04 .2011 & $20-40$ & Posidonia \\
\hline BT15 & $40^{\circ} 08^{\prime} 51^{\prime \prime}$ & $25^{\circ} 58^{\prime} 34^{\prime \prime}$ & 05.04 .2011 & $20-40$ & Posidonia \\
\hline BT16 & $40^{\circ} 11^{\prime} 48^{\prime \prime}$ & $25^{\circ} 58^{\prime} 48^{\prime \prime}$ & 05.04 .2011 & $20-40$ & Posidonia \\
\hline BT17 & $40^{\circ} 14^{\prime} 12^{\prime \prime}$ & $25^{\circ} 54^{\prime} 17^{\prime \prime}$ & 08.04 .2011 & $20-40$ & Gravel \\
\hline BT18 & $40^{\circ} 14^{\prime} 14^{\prime \prime}$ & $25^{\circ} 56^{\prime} 17^{\prime \prime}$ & 08.04 .2011 & $25-35$ & Posidonia \\
\hline BT19 & $40^{\circ} 14^{\prime} 02^{\prime \prime}$ & $25^{\circ} 57^{\prime} 00^{\prime \prime}$ & 08.04 .2011 & $25-35$ & Posidonia \\
\hline BT20 & $40^{\circ} 1335^{\prime \prime}$ & $25^{\circ} 57^{\prime} 25^{\prime \prime}$ & 08.04 .2011 & $25-35$ & Posidonia \\
\hline K1 & $40^{\circ} 14^{\prime} 04^{\prime \prime}$ & $25^{\circ} 54^{\prime} 11^{\prime \prime}$ & 02.06 .2011 & 0.5 & Rocky \\
\hline$\underline{\mathrm{K}} 2$ & $40^{\circ} 14^{\prime} 04^{\prime \prime}$ & $40^{\circ} 14^{\prime} 04^{\prime \prime}$ & 03.06 .2011 & 0.5 & Rocky \\
\hline
\end{tabular}

Echinoderms were separated under a stereomicroscope and preserved in 70\% ethanol. Spicules of Holothuria species were removed from various body parties in heated household bleach, washed and observed under a light microscopy. Temperature, salinity, dissolved oxygen concentration, $\mathrm{pH}$, TDS and conductivity were measured on board by using the YSI 556 Multiprobe system (Table 1).

Soyer's Frequency index (F) was used to describe ecological importance of species. According to Soyer, species with $\mathrm{F}>50 \%$ are considered constant, those with $\mathrm{F}$ between 25 and $50 \%$ are common while those with $\mathrm{F}$-values $<25 \%$ are considered rare. Multivariate analyses were applied on presence/ absence data of echinoderm species using the PRIMER package Ver. 5.0 (Clarke and Warwick, 2001). Bray-Curtis similarity and Analyses of Similarity (ANOSIM) were used to assess and compare patterns of species distribution from Gokceada island and adjacent water. SIMPER analysis was performed to examine the contribution of each species to the similarity/dissimilarity among the groups identified from the clusters analysis.

\section{RESULTS AND DISCUSSION}

Surface water temperature ranged from $11.05-12.78^{\circ} \mathrm{C}$. Regarding salinity, the minimum value of surface water salinity was 30.36 psu while the maximum reached 34.43 psu. $\mathrm{pH}$ was quite similar at all stations ranging from 8.2-8.3. Total Dissolved Solids (TDS) ranged from 30.46 (Station BT11) to 34.20 (Station BT14). Dissolved oxygen had its minimum at Station BT5 $\left(9 \mathrm{mg} \mathrm{L}^{-1}\right)$ and maximum at Station BT11 $\left(9.45 \mathrm{mg} \mathrm{L}^{-1}\right)$. The minumum conductivity value $\left(46.86 \mathrm{mS} \mathrm{cm}^{-1}\right)$ was measured at Station BT1 1 and the maximum $\left(52.39 \mathrm{mS} \mathrm{cm}^{-1}\right)$ at Station BT16.

A total of 626 specimens belonging to 25 Echinoderm species (7 Asteroidea and Echinoidea, 6 Ophiuroidea, 4 Holothurioidea and 1 Crinoidea) were caught in the study area.

Although, the highest species number was found at Station BT4 (10 species), the highest specimens number was found at Station BT3 (110 individuals). Additionaly, no Echinoderm specimens were obtained at Stations BT12, BT13 and BT13a were obtained from Psammechinus microtuberculatus (Blainville, 1825) showed the maximum number of specimens (301). In terms of frequency of occurence, $P$. microtuberculatus was the only constant species $(\mathrm{F}=54.2 \%)$, the commonest species was Ophiura albida $(\mathrm{F}=42 \%)$ followed by Ophiura ophiura $(29.2 \%)$ and Paracentrotus lividus (25\%). The other 21 species were rare (Table 2).

Results from cluster analysis, performed applying presence/absence data of the community to the BrayCurtis similarity index are shown in Fig. 2.

According to the results of the Cluster analysis based on the precence/absence of Echinoderm species (Fig. 3), Gokceada island was similar to Bozcada island at about $57.7 \%$ and the Canakkale strait was linked at a similar level of $37.3 \%$. However, they were not found to be statistically different ( $\mathrm{p}=0.3$, ANOSIM).

SIMPER was used to identify, the percentage contribution of each species made to the measure of similarity/dissimilarity. H. mammata, Stichopus regalis, 
Table 2: Species composition, abundance/station, total abundance $(N)$ and Frequency $(F)$ of echinoderm fauna collected from Gokceada island coasts

\begin{tabular}{|c|c|c|c|c|c|c|c|c|c|c|c|c|c|c|c|c|c|c|c|c|c|c|c|c|c|c|c|}
\hline \multirow[b]{2}{*}{ Species composition } & \multicolumn{23}{|c|}{ Stations/Beam-trawl } & \multicolumn{4}{|c|}{ Shore } \\
\hline & 1 & 2 & 3 & 4 & 5 & $5 \mathrm{a}$ & 6 & 7 & 8 & 9 & 10 & 11 & & & $13 a$ & 14 & 15 & 16 & 17 & 18 & $3 \quad 19$ & & $20 \mathrm{I}$ & $\mathrm{K} 1$ & $\mathrm{~K} 2$ & $\mathrm{~N}$ & $\mathrm{~F}$ \\
\hline $\begin{array}{l}\text { Antedon mediterranea } \\
\text { (Lamarck, 1816) }\end{array}$ & - & 1 & - & 3 & - & - & - & - & - & - & - & - & - & - & - & - & 1 & - & - & 6 & 1 & & - & - & - & 12 & 20.8 \\
\hline $\begin{array}{l}\text { Ophiura ophiura } \\
\text { (Linnaeus, 1758) }\end{array}$ & 2 & 1 & - & 1 & 26 & - & - & - & - & - & - & - & - & - & - & - & - & - & 4 & - & 25 & & 1 & - & - & 60 & 29.2 \\
\hline $\begin{array}{l}\text { Ophiura albida } \\
\text { (Forbes, 1839) }\end{array}$ & 19 & - & 1 & 4 & 11 & 1 & 1 & - & - & 1 & - & - & - & - & - & 1 & - & - & 5 & - & 2 & & - & - & - & 46 & 41.7 \\
\hline $\begin{array}{l}\text { Ophiura grubei } \\
\text { (Heller, 1863) }\end{array}$ & 22 & - & - & 1 & - & - & - & - & 1 & - & - & - & - & - & - & - & - & - & - & - & 1 & & - & - & - & 4 & 16.7 \\
\hline $\begin{array}{l}\text { Ophiothrix fragilis } \\
\text { (Abildgaard, 1789) }\end{array}$ & - & 4 & 1 & 3 & 1 & - & - & - & - & - & - & - & - & - & - & - & - & - & - & 4 & - & & - & - & - & 25 & 20.8 \\
\hline $\begin{array}{l}\text { Ophioderma longicaudum } \\
\text { (Retzius, 1805) }\end{array}$ & i & - & - & 1 & - & - & - & 1 & - & - & - & - & - & - & - & 1 & - & - & - & - & - & . & - & - & - & 13 & 12.5 \\
\hline $\begin{array}{l}\text { Amphipholis squamota } \\
\text { (Delle Chiaje, 1828) }\end{array}$ & - & - & - & - & - & - & - & - & - & - & - & - & - & - & - & - & - & - & - & - & - & & - & 1 & - & 1 & 4.2 \\
\hline $\begin{array}{l}\text { Asterina gibbosa } \\
\text { (Pennant, 1777) }\end{array}$ & - & 4 & - & 3 & - & - & - & - & - & - & - & - & - & - & - & - & - & - & - & 9 & - & & - & - & - & 16 & 12.5 \\
\hline $\begin{array}{l}\text { Asterina pancerii } \\
(\text { Gasco, } 1870)\end{array}$ & - & - & - & - & - & - & - & - & - & - & - & - & - & - & - & - & - & - & - & 2 & - & & - & - & - & 2 & 4.2 \\
\hline $\begin{array}{l}\text { cten spinulosus } \\
\mathrm{i}, 1837)\end{array}$ & - & 2 & - & - & - & - & - & - & - & - & - & - & - & - & - & - & - & - & - & 2 & - & & - & - & - & 4 & 8.3 \\
\hline $\begin{array}{l}\text { Astropecten aranciacus } \\
\text { (Linnaeus, 1758) }\end{array}$ & 2 & - & - & - & 6 & - & - & - & - & - & - & - & - & - & - & 1 & - & - & - & - & - & & 5 & - & - & 14 & 16.7 \\
\hline $\begin{array}{l}\text { Echinaster sepositus } \\
\text { (Retzius, 1783) }\end{array}$ & - & - & - & 2 & 2 & - & - & - & - & - & 1 & - & - & - & - & - & - & - & - & 2 & - & & - & - & - & 7 & 16.7 \\
\hline $\begin{array}{l}\text { Luidia cilioris } \\
\text { (Philippi, 1837) }\end{array}$ & - & - & - & - & - & - & - & - & - & - & 1 & 1 & - & - & - & - & - & - & - & - & - & & - & - & - & 2 & 8.3 \\
\hline $\begin{array}{l}\text { Luidia sarsi } \\
\text { (Duben-Koren, 1846) }\end{array}$ & - & - & - & - & - & - & - & - & - & - & - & - & - & - & - & - & - & - & 1 & - & - & & - & - & - & 1 & 4.2 \\
\hline Arbacia lixula & - & - & - & - & - & - & - & - & - & - & - & - & - & - & - & - & - & - & - & - & - & & -2 & 252 & 20 & 45 & 8.3 \\
\hline $\begin{array}{l}\text { Pscanmechinus } \\
\text { microtuberculatus } \\
\text { (Blainville, 1825) }\end{array}$ & - & 3210 & & 15 & 29 & 1 & - & - & - & - & - & - & - & - & - & - & - & 51 & 2 & 7 & 12 & & 4 & - & - & 301 & 54.2 \\
\hline $\begin{array}{l}\text { Poracentrotus lividus } \\
\text { (Lamarck, 1816) }\end{array}$ & 1 & - & - & - & - & - & - & - & - & - & - & - & - & - & - & - & - & - & - & 3 & - & & 12 & 202 & 25 & 51 & 25.0 \\
\hline $\begin{array}{l}\text { Sphaerechinus granularis } \\
\text { (Lamarck, 1816) }\end{array}$ & - & 2 & 3 & 1 & 1 & - & - & - & 1 & 14 & 41 & - & - & - & - & - & - & 1 & - & - & - & 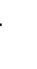 & - & - & - & 8 & 20.8 \\
\hline $\begin{array}{l}\text { Spatongus purpureus } \\
\text { (O.F. Muller, 1776) }\end{array}$ & 1 & - & - & - & - & - & - & 1 & - & - & - & - & - & - & - & - & - & - & - & - & 1 & & - & - & - & 2 & 8.3 \\
\hline $\begin{array}{l}\text { Echinocyamus pusillus } \\
\text { (O.F. Muller, 1776) }\end{array}$ & - & 1 & - & - & - & - & - & - & - & - & - & - & - & - & - & - & - & 1 & - & - & - & & - & - & - & 2 & 8.3 \\
\hline $\begin{array}{l}\text { Echinocardium cordatum } \\
\text { (Pennant, 1777) }\end{array}$ & - & - & - & - & - & - & - & - & - & - & - & - & - & - & - & - & - & - & - & - & 1 & & - & - & - & 4 & 12.5 \\
\hline Holothuria impatiens & - & - & - & - & - & - & - & - & - & - & - & - & - & - & - & - & - & - & - & - & 1 & & - & - & - & 1 & 4.2 \\
\hline $\begin{array}{l}\text { Holothuria mammata } \\
\text { (Grube, } 1840 \text { ) }\end{array}$ & - & - & - & - & - & - & - & 1 & - & 2 & - & - & - & - & - & - & 1 & - & - & - & - & & - & - & - & 1 & 4.2 \\
\hline $\begin{array}{l}\text { Holothuria polii } \\
\text { (Delle Chiaje, 1823) }\end{array}$ & - & - & - & - & - & - & - & - & - & - & - & - & - & - & - & - & 4 & - & - & - & - & . & - & - & - & 4 & 4.2 \\
\hline $\begin{array}{l}\text { Holothuria tubulosa } \\
\text { (Gmelin, 1788) }\end{array}$ & - & - & - & - & - & - & - & - & - & - & - & - & - & - & - & - & - & - & - & 1 & - & & - & - & - & 1 & 4.2 \\
\hline of species & 6 & 8 & 4 & 1 & 7 & 2 & . & & & 3 & 3 & 1 & 0 & 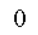 & 0 & 2 & 4 & 3 & 4 & 8 & 8 & & 4 & 3 & 3 & - & - \\
\hline Total specimens & 47 & 4711 & & 34 & 76 & 2 & 1 & 3 & & 44 & 43 & 1 & 0 & 0 & 0 & & 1 & 53 & 12 & 35 & 44 & 1 & 14 & 164 & 46 & 626 & - \\
\hline
\end{tabular}

E. sepositus, $P$. microtuberculatus, $P$. lividus, $A$. lixula, S. granularis, E. pusillus, E. cordatum, A. gibbosa, $A$. pancerii, $A$. aranciacus, $A$. mediterranea and $O$. albida showed the highest similarity by the same species contribution (7.14\%) both in Bozcaada and Gokceada islands. Genocidaris maculata A. (Agassiz, 1869) Leptopentacta tergestina (Sars, 1857), Leptosynapta inhaerens (Muller, 1776), Thyone fusus
(Muller, 1776), H. mammata, S. regalis, E. sepositus, A. lixula, S. granularis, E. pusillus, E. cordatum, Amphiura cherbonnieri (Guille, 1972), Amphiura securigera (Duben and Koren, 1846), Ophiopsila annulosa (Sars, 1859), Ophiopsila arenea (Forbes, 1845), Asterias rubens (Linnaeus, 1758), Astropecten platycanthus (Philippi, 1837), A. pancerii, Leptometra phalangium (Muller, 1841) and Antedon mediterranea 


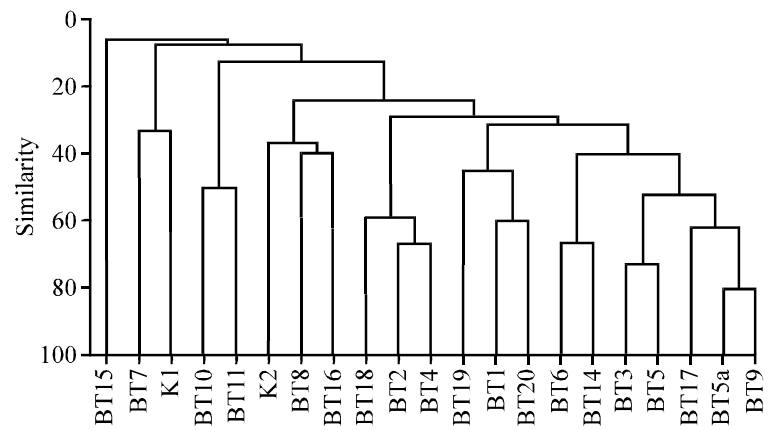

Fig. 2: Cluster analysis in each Stations in Gokceada island

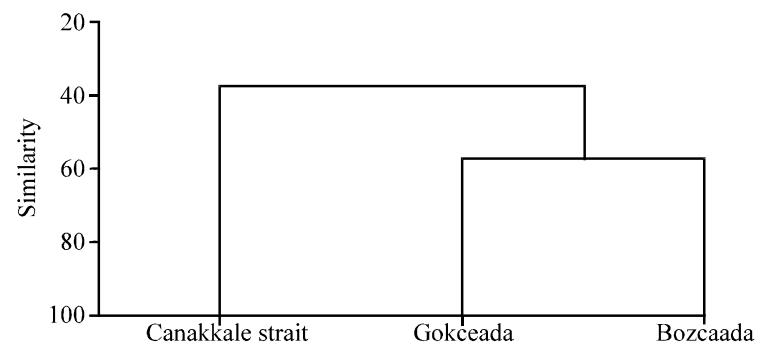

Fig. 3: Cluster analysis of the Canakkale strait and Islands of Gokceada and Bozcaada

were the most abundant discriminator species between the Canakkale strait and the islands (contribution 3.18\%). This study has made it possible to determine 25 Echinoderm species, 21 of them being new records for Gokceada island. Thus, the number of species from the island has increased to 30 which corresponds to the $35 \%$ of the total number of Echinoderm species (86) reported from Turkish coast (Aslan-Cihangir and PancucciPapadopoulou, 2011). According to the literature, 23 Echinoderm species have been reported from Bozcada island and 26 from the Canakkale strait (Aslan-Cihangir and Pancucci-Papadopoulou, 2011) in adjacent waters to Gokceada island. However, 107 species have been recorded from Greece coasts (PancucciPapadopoulou and Hetaireia, 1996).

Bray-Curtis similarity index, SIMPER and ANOSIM took into account for presence/absence of Echinoderm species in Bozcaada and Gokceada island and the Canakkale strait.

\section{CONCLUSION}

This study shows that the Canakkale strait was different from both islands. It has been thought that the main reason may be the differences of using sampling tools. In addition, the depth and habitat were different in these areas. But at the result of ANOSIM, they were not found to be statistically different. The characteristics of the surface water of the Northern Aegean sea that surrounds the islands under the influence of Black sea waters through Canakkale strait and therefore, surface salinity varies seasonally between 26-35 psu (Yuce, 1995). The researchers think that the number of Echinoderm species known from the Turkish North Aegean sea will increase significantly if future research will extensively cover all kinds of habitats including those deeper than $45 \mathrm{~m}$.

\section{ACKNOWLEDGEMENTS}

This research was supported by the COMU-BAP (Scientific Research Project) under the Project No. of 2010/138. The researcher is gratefull to all student of Department of Fisheries Technology, Gokceada School of Applied Sciences, Canakkale Onsekiz Mart University for their helping to take sampling and to Dr. M. Antonietta Pancucci-Papadopoulou for her valueable comments.

\section{REFERENCES}

Aslan-Cihangir, H. and M.A. Pancucci-Papadopoulou, 2011. Spatial and temporal variation of echinoderm assemblages from soft bottoms of Canakkale Strait (Turkish Strait System) with a taxonomic key of the genus Amphiura (Echinodermata: Ophiuroidea). Turk. J. Zool., (In Press).

Cinar, M.E., T. Katagan, Z. Ergen and M. Sezgin, 2002. Zoobenthos-inhabiting Sarcotragus muscarum (Porifera: Demospongiae) from the Aegean Sea. Hydrobiologia, 482: 107-117.

Clarke, K.R. and R.M. Warwick, 2001. Change in Marine Communities: An Approach to Statistical Analysis and Interpretation. 2nd Edn., PRIMER-E: Plymouth Marine Laboratory, United Kingdom.

Ozaydin, O., T. Katagan and S. Unsal, 1995. The echinoderms of the Turkish seas. Isr. J. Zool., 41: 57-68.

Pancucci-Papadopoulou, M.A. and H.Z. Hetaireia, 1996. The Echinodermata of Greece: Fauna Graeciae. Vol. 6. Hellenic Zoological Society, Athens, ISBN: 9789608529830, Pages: 162.

Yuce, H., 1995. Northern aegean water masses. Estuar. Coast. Shelf Sci., 41: 325-343.

Zaitsev, Y. and B. Ozturk, 2001. Exotic species in the Aegean, Marmara, Black, Azov and Caspian Seas. Turkish Marine Research Foundation, Istanbul, Turkey, Pages: 265. 